\title{
MAZHAB FILSAFAT PENDIDIKAN DAN IMPLIKASINYA TERHADAP PENDIDIKAN ISLAM
}

\author{
Mustafa
}

\begin{abstract}
Abstrak
Menemukan makna dan arah pendidikan adalah sebuah pencarian yang panjang, karena pendidikan seirama dengan dinamika kehidupan dimana manusia itu hidup. Adanya rumusan tentang konsep pendidikan itu dilatar belakangi oleh faktor yang mengitarinya seperti nilai-nilai teologis, normatif, sosiologis, geografis, ekonomi, budaya dan agama. Dalam arti selain dari pertimbangan nilai teologis- normatif, maka dasar pendidikan juga memuat nilai historis, yaitu perkembangan pemikiran pendidikan dari waktu yang tidak terbatas, karenanya sangat banyak paradigma pendidikan sebagai muatan pemikiran untuk merekonstruksinya. Sehingga berbagai aliran dan mazhab dalam pendidikan menjadi pertimbangan dalam memberikan formulasi karena muatan kajiannya berdasarkan pertimbangan dan kepentingan dalam pendidikan. Disebabkan itu lahirnya berbagai mazhab dalam pendidikan sekalipun ada perbedaan pandangan dalam pendidikan agar kita dapat melihat aspek dan arah yang menjadi kajian masing-masingnya untuk dijadikan perbincangan karena dapat dikatakan antara pendidikan Islam dan Barat memiliki persamaan dan perbedaan.
\end{abstract}

\section{Kata Kunci: Mazhab-Pendidikan}

\section{Pendahuluan}

Pemikiran (filsafat) pendidikan Islam tidak bisa juga dilepaskan dari alur pemikiran yang dikembangkan oleh para pemikirnya. Selama ini pemikiran filsafat pendidikan pada umumnya dikategorikan ke dalam dua kelompok (aliran), yaitu : pertama, aliran filsafat kritis dalam pendidikan atau masa pemikiran yang bersifat maju atau progresif dalam pemikiran, dan yang kedua, aliran atau mazhab pemikiran filsafat pendidikan yang bersifat tradisional. Ukuran maju atau progresif dan tradisional biasanya dilihat dari sejauh mana peranan pendidikan dan anak didik keseluruhan upaya pendidikan. Konsep pendidikan bersifat tradisional bila 
menekankan peranan pendidik dan hal-hal di luar anak didik. Dalam alam pendidikan tradisional anak didik seolah-olah dijadikan obyek pasif yang perlu disesuaikan terhadap hal-hal yang berada di luar dirinya. Sebaliknya suatu konsep pendidikan bersifat maju atau progresif apabila ia menempatkan anak didik itu sendiri. Kedua konsep tersebut terus mempertahankan diri dan berkembang dengan keunggulan dan kelemahan masing-masing.

Dalam pemikiran pendidikan Islam juga dikelompokkan ke dalam dua alur pemikiran dalam menjawab persoalan pendidikan, sebagaimana temuan penelitian Abdullah yaitu : pertama, kelompok yang berusaha mengangkat konsep pendidikan Islam dari al-Qur'an dan al-Hadits saja, sehingga konsep filsafatnya hanya berasal dari kedua sumber ajaran Islam tersebut ; dan kedua, kelompok yang menghendaki adanya keterbukaan terhadap pandangan hidup non Islami dan berusaha meminjam serta memasukkan konsep pemikirannya ke dalam filsafat pendidikan Islam. ${ }^{1}$

Bertolak dari pandangan diatas, teori postmodern menjadi salah satu landasan filosofis dalam pengembangan ilmu pendidikan Islam, dengan melakukan modifikasi konsep yang tidak begitu saja mengadopsi pemikiran postmodernis, justru ia melakukan kontekstualisasi dengan ajaran Islam. Oleh karena itu perkembangan pemikiran dalam pendidikan dapat dipetakan sehingga menjadi tipologi-tipologi pemikiran. Di Amerika Serikat berkembang aliran-aliran pemikiran (filsafat)

\footnotetext{
${ }^{1}$ Abdurrahman Saleh Abdullah, Education Theory A Quranic Out-look, (Makalah alMukarramah: Umm al-Qura University, 1982), h. 35-36.
} 
pendidikan, yang dapat dipetakan kedalam dua kelompok, yaitu tardisional dan kontemporer. Sedangkan yang termasuk dalam kedalam lompok kontemporer adalah progresivism, Rekonstructionism, dan Existentialism. Sedangkan aliran Perenialisme, Essensialisme masuk kepada aliran tradisional.

Dalam lapangan pendidikan, masing-masing aliran tersebut terwujud dalam kemungkinan-kemungkinan sikap dan pendirian para pendidik, seperti (1) sikap konservatif, yakni mempertahankan nilai-nilai budaya manusia, sebagai perwujudan dari essensialism; (2) Sikap regresif, yakni kembali kepada jiwa manusia yang menguasai abad pertengahan, yaitu agama, sebagai perwujudan dari perenialism; (3) sikap bebas dan modifikatif sebagai perwujudan dari progresivism; (4) sikap radikal rekonstruktif sebagai perwujudanReconstrucionism; dan (5) sikap yang menekankan keterlibatan peserta didik dala kehidupan empiris utuk mencari pilihan dan menemukan jati dirinya, atau menurut Brubacher (1982): ”...in the end the learner's identity is fiund in his commitments. What he chooses, that he becomes adalah perwujudan dari exsistentialism.

Oleh karena itu wilayah kajian pemikiran (filsafat) pendidikan dapat lihat dari berbagai dimensi, Buchari melihat dua dimensi, yaitu dimensi lingkungan 
pendidikan, dan dimensi jenis permasalahan pendidikan. ${ }^{2}$ Dan dapat ditambahkan dengan dimensi waktu, dan dimensi ruang geografis. ${ }^{3}$

Muhaimin mencoba lebih mengembangkan kearah yang lebih metodologis dan praktis, yang berangkat dari teori dan pemetaan pemikiran dan juga menilai secara historis-sosiologis pendidikan dengan di direduksi kepada pengembangan yang lebih praktis sesuai dengan pengembangan disekolah. Maka dalam penelitian akan dicoba yang dimulai dari teori kemudian bagaimana implikasinya terhadap pengembangan pendidikan Islam kedepan.

Di bawah ini dapat dilihat wilayah kajian pemikiran (filsafat), yang meliputi dimensi sumber, ide dasar dalam pemikiran pendidikan, dan persoalan-persoalan pendidikan sebagai lingkup kajian.

Berdasarkan latar belakang yang telah diutarakan terdahulu dapat dirumuskan masalah sebagai berikut:

1. Bagaimana karakteristik aliran-aliran dalam filsafat ?

2. Bagaimana implikasi aliran-aliran terhadap pendidikan Islam ?

\footnotetext{
${ }^{2}$ Muchtar Buchari, Ibid, h. 15.

${ }^{3}$ Soedomo, M., Aktualisasi Pengembangan Ilmu Pendidikan Islam Dalam Pembangunan Nasional (Malang : IKIP, 1990), h. 21.
} 


\section{Pembahasan}

Dalam proses pertumbuhannya, filsafat sebagai hasil pemikiran para ahli filsafat atau para filosof sepanjang kurun waktu dengan obyek permasalahan hidup di dunia, telah melahirkan berbagai macam pandangan. Pandangan-pandangan para filosof itu, ada kalanya satu dengan yang lain hanya bersifat saling kuat menguatkan, tetapi tidak jarang pula yang berbeda atau berlawanan. Hal ini antara lain disebabkan terutama oleh pendekatan yang dipakai oleh mereka berbeda, walaupun untuk obyek permasalahannya sama. Karena perbedaan sistem pendekatan itu, maka kesimpulan yang dihasilkan menjadi berbeda pula, bahkan tidak sedikit yang saling berlawanan. Selain itu faktor zaman dan pandangan hidup yang melatar belakangi mereka, serta tempat di mana mereka bermukim juga ikut mewarnai pemikiran mereka.

Menyimak kembali sejarah pertumbuhan dan perkembangan filsafat menjadi jelas adanya perbedaan dalam pemahaman realita pemikiran ilmu pengetahuan dalam filsafat. Begitu pula halnya dengan filsafat pendidikan, bahwa dalam sejarahnya telah melahirkan berbagai pandangan atau aliran. Karena pemikiran filsafat tidak pernah mandeg, maka keputusan atau kesimpulan yang diperolehpun tidak pernah merupakan kesimpulan final. Oleh sebab itu, dunia percaturan filsafat-termasuk di dalamnya filsafat pendidikan-sering kali hanya berkisar pada permasalahan yang itu-

itu juga, baik sebagai suatu bentuk persetujuan ataupun penolakan terhadap kesimpulan yang ada. Muhammad Noorsyam melukiskan keadaan dunia pemikiran filsafat itu, sebagai berikut: 
Nur Syam mengatakan, bagaimanapun wujud reaksi, aksi, cita-cita, kreasi bahkan pemahaman manusi, atas segala sesuatu termasuk kepribadian ideal mereka, tersimpul di dalam pokok-pokok ajaran suatu filsafat. Pengertian masingmasing pribadi tentang suatu kesimpulan sebagai belum final, belum valid, tidak mutlak dan sebagainya, memberi kebebasan pada setiap orang untuk menganut atau menolak suatu aliran. Sikap demikian justru menjadi prakondisi bagi perkembangan aliran-aliran filsafat. Sikap ini dikenal dalam filsafat dengan istilah eclectic atau eclecticism". ${ }^{4}$

Untuk mengenal perkembangan pemikiran dunia filsafat pendidikan, di bawah ini akan diuraikan garis-garis besar aliran-aliran filsafat dalam pendidikan, yaitu: Aliran Progressivisme, Aliran Esensialisme, Aliran Perennialisme, Aliran Rekonstruksionalisme, Aliran Eksistensialisme.

\section{ALIRAN-ALIRAN FILSAFAT DALAM PENDIDIKAN}

\section{A. Aliran Progressivisme}

Aliran progresivisme adalah suatu aliran, filsafat pendidikan yang sangat berpengaruh dalam abad ke 20 ini. Pengaruh itu terasa di seluruh dunia, terlebihlebih di Amerika Serikat. Usaha pembaharuan di dalam lapangan pendidikan pada umumnya terdorong oleh aliran progressivisme ini.

Biasanya aliran progressivisme ini dihubungkan dengan pandangan hidup

${ }^{4}$ M. Noorsyam, Pengantar Filsafat Pendidikan, (Malang: IKIP Malang, 1978), h. 34-35 
liberal-"The liberal road to culture". 5 Yang dimaksudkan dengan ini ialah pandangan hidup yang mempunyai sifat-sifat sebagai berikut: fleksibel (tidak kaku, tidak menolak perubahan, tidak terikat oleh suatu doktrin tertentu), curious (ingin mengetahui, ingin menyelidiki), toleran dan open-minded (mempunyai hati terbuka).

\section{Sifat-sifat aliran progressivisme}

Sifat-sifat umum aliran progressivisme dapat diklasifikasikan dalam dua kelompok: (a) sifat-sifat negatif, dan (b) sifat-sifat posif.

Sifat itu dikatakan negatif dalam arti bahwa, progressivisme menolak otoritarisme dan absolutisme dalam segala bentuk, seperti halnya terdapat dalam agama, politik, etika dan epistemologi positif dalam arti, bahwa progressivisme menaruh kepercayaan terhadap kekuatan alamiah dari manusia, kekuatankekuatan yang diwarisi oleh manusia dari alam sejak ia lahir - man's natural powers. Terutama yang dimaksud ialah kekuatan-kekuatan manusia untuk terus-menerus melawan dan mengatasi kekuatan-kekuatan, takhayu1-takhayul dan kegawatankegawatan yang timbul dari lingkung hidup yang selamanya mengancam.

Istilah filsafat yang biasanya dipakai untuk menggambarkan pandangan hidup yang demikian disebut pragmatisme. Dalam lapangan pendidikan lebih lazim dipakai istilah-istilah "instrumentalisme" dan "experimentalisme". Dalam arti terbatas pragmatisme adalah suatu teori pikir. Menurut John Dewey

${ }^{5}$ Theodore Brameld, The Pattern of Educational Philosophy, The Mac. Milian Company, New York, 1956. 
pragmatisme ialah : "the rule of referring all thinking to consequences for final meaning and test." ${ }^{6}$ Untuk mengetahui apakah pikir itu benar, perlu dilihat hasil pikiran itu. Jika pikiran itu berhasil, mempunyai arti bagi si pemikir, maka pikiran itu benar. Ini berarti pragmatisme, dipakai dalam arti yang lebih luas, menurut Dewey. Akan tetapi lazim juga istilah pragmatisme yaitu meliputi sekelompok keyakinan-keyakinan filsafat mengenai alam dan manusia.

Progressivisme yakin bahwa manusia mempunyai kesanggup-kesanggupan untuk mengendalikan hubungannya dengan alam, iggup meresapi rahasiarahasia alam, sanggup menguasai alam. tetapi di samping keyakinan-keyakinan ini ada juga kesangsi Dapatkah manusia menggunakan kecakapannya dalam ilmu-ilmu pengetahuan alam, juga dalam ilmu pengetahuan sosial? Dalam masyarakat manusia? Dalam hubungannya dengan sesama manusia? Pragmatisme (dan progressivisme) yakin bahwa manusia mempunyai kesanggupan itu, akan tetapi apakah manusia dapat belajar bagaimana mempergunakan kesanggupan itu dalam hal ini, di sini timbul sedikit kesangsian. Tetapi, meskipun demikian progressivisme tetap bersikap optimis, tetap percaya bahwa manusia dapat menguasai seluruh lingkungannya, lingkungan alam dan lingkungan sosial.

Maka tugas pendidikan menurut pragmatisme, ialah meneliti sejelas-jelasnya kesanggupan-kesanggupan manusia itu dan menguji kesanggupan-kesanggupan itu dalam pekerjaan praktis. Yang dimaksud di sini ialah, bahwa manusia

${ }^{6}$ Joe Park, Selected Readings in the Philosophy of Education, New York, Mackn Publishing Co, Inc. 1974), $\mathrm{h}$. 
hendaknya memperkerjakan ide-ide atau pikiran-pikirannya. Manusia tidak hendaknya berpikir melulu untuk kesenangan berpikir saja, manusia hendaknya berpikir untuk berbuat. Pragmatisme menolak "pure intellectualis$m e "$. Bagi pragmatisme, jiwa dan pikiran manusia dipakai menghadapi tugas hidup yang maha besar. Pragmatisme menolak pendapat, bahwa manusia itu tidak berdaya; bahwa manusia hanya dapat menyerah saja kepada kekuatankekuatan dalam lingkungannya. Pragmatisme berpendapat, bahwa pendidikan adalah alat kebudayaan yang paling baik. Bahwa dengan pendidikan sebagai alat, manusia dapat menjadi "the masters, not the slaves. of social as well as other kinds of natural change". ${ }^{7}$

2. Keyakinan-keyakinan progressivisme tentang pendidikan

Istilah progressivisme dalam bagian ini akan dipakai dalam hubungannya dengan pendidikan, dan menunjukkan sekelompok keyakinan-keyakinan yang tersusun secara harmonic dan sistematis dalam hal mendidik. Keyakinan-keyakinan mana didasarkan pada sekelompok keyakinan-keyakinan filsafat yang lazim disebut orang pragmatisme, instrumentalisme dan eksperimentalisme.

Perlu diketahui bahwa pragmatisme sebagai filsafat dan progressivisme sebagai pendidikan erat sekali hubungannya dengan kepercayaan yang sangat luas dari John Dewey dalam lapangan pendidikan. Hal ini dengan jelas dapat ditelusuri lewat bukunya, Democracy And Education. Dalam bukunya inilah Dewey mem-

${ }^{7}$ Ibid 
perlihatkan keyakinan-keyakinan dan wawasan-wawasannya tentang pendidikan, serta mempraktekkannya di sekolah-sekolah yang ia dirikan. Menurut Dewey tujuan umum pendidikan ialah warga masyarakat yang demokratis. Isi pendidikannya lebih mengutamakan bidang-bidang studi, seperti, IPA, sejarah, keterampilan, serta hal-hal yang berguna atau langsung dirasakan oleh masyarakat. Metode scientific lebih dipentingkan, dan bukan metode memorisasi seperti pada aliran esensialisme. Praktek kerja di laboratorium, di bengkel, di kebun (lapangan) merupakan kegiatan yang dianjurkan dalam rangka terlaksananya "learning by doing". Progressivisme tidak menghendaki adanya mata pelajaran yang diberikan secara terpisah, melainkan harus diusahakan terintegrasi dalam unit. Karena perubahan yang selalu terjadi maka diperlukan fleksibilitas dalam pelaksanaannya, dalam arti tidak kaku, tidak menghindar dari perubahan, tidak terikat oleh doktrin tertentu, bersifat ingin tabu, toleran, dan berpandangan luas serta terbuka.

\section{B. Aliran Esensialisme}

Esensialisme muncul pada zaman Renaissans, dengan ciri-ciri utamanya yang berbeda dengan progressivisme. Perbedaan ini terutama dalam memberikan dasar berpijak mengenai pendidikan yang penuh fleksibelitas, di mana serba terbuka untuk perubahan, toleran dan tidak ada keterikatan dengan doktrin tertentu. Bagi esensialisme, pendidikan yang berpijak pada dasar pandangan itu mudah goyah dan kurang terarah. Karena itu esensialisme memandang bahwa pendidikan harus berpijak pada nilai-nilai yang memiliki kejelasan dan 
tahan lama, sehingga memberikan kestabilan dan arah yang jelas. ${ }^{8}$

Esensialisme didasari atas pandangan humanisme yang merupakan reaksi terhadap hidup yang mengarah pada keduniawian, serba ilmiah dan materialistik. Selain itu juga diwarnai. oleh pandangan-pandangan dari paham penganut aliran idealisme dan realisme. Imam Barnadib $(1981)^{9}$, menyebutkan beberapa tokoh utama yang berperan dalam penyebaran aliran esensialisme, yaitu:

1. Desiderius Erasmus, humanis Belanda yang hidup pada akhir abad 15 dan permulaan abad 16, yang merupakan tokoh pertama yang menolak pandangan hidup yang berpijak pada dunia lain. Erasmus berusaha agar kurikulum sekolah bersifat humanistic dan bersifat internasional, sehingga bisa mencakup lapisan menengah dan kaum aristokrat.

2. Johann Amos Comenius yang hidup diseputar tahun 1592-1670, adalah seorang yang memiliki pandangan realis dan dogmatic. Comenius berpendapat bahwa pendidikan mempunyai peranan membentuk anak sesuai dengan kehendak Tuhan, karena pada hakikatnya dunia adalah dinamis dan bertujuan.

3. John Locke, tokoh dari Inggris yang hidup pada tahun 1632-1704 sebagai pemikir dunia berpendapat bahwa pendidikan hendaknya selalu dekat dengan situasi dan kondisi. Locke mempunyai sekolah kerja untuk anakanak miskin.

${ }^{8}$ Ibid., h. 84

${ }^{9}$ Imam Barnadib, FlIsafat Pendidikan, Cet. IX, Yogyakarta: Yayasan Penerbit FIP IKIP, hal. 38-40. 
4. Johann Henrich Pestalozzi, sebagai seorang tokoh yang berpandangan naturalistis yang hidup pada tahun 1746-1827. Pestalozzi mempunyai kepercayaan bahwa sifat-sifat alam itu tercermin pada manusia, sehingga pada diri manusia terdapat kemampuan-kemampuan wajarnya. Selain itu ia mempunyai keyakinan bahwa manusia juga mempunyai hubungan transendental langsung dengan Tuhan.

5. Johann Friederich Frobel (1782-1852) sebagai tokoh yang berpandangan kosmis_-sintetis dengan keyakinannya bahwa manusia adalah makhluk ciptaan Tuhan yang merupakan bagian dari alam ini, sehingga manusia tunduk dan mengikuti ketentuan-ketentuan hukum alam. Terhadap pendidikan Frobel memandang anak sebagai makhluk yang berekspresi kreatif, yang dalam tingkah lakunya akan nampak adanya kualitas metafisis. Karenanya tugas pendidikan adalah memimpin anak didik ke arah kesadaran diri sendiri yang murni, selaras dengan fitrah kejadiannya.

6. Johann Friederich Herbert yang hidup pada tahun 1776-1841, sebagai salah seorang murid Immanuel Kant yang berpandangan kritis, Herbert berpendapat bahwa tujuan pendidikan adalah menyesuaikan jiwa seseorang dengan kebajikan dari yang Mutlak dalam arti penyesuaian dengan hukum-hukum kesusilaan dan inilah yang disebut proses pencapaian tujuan pendidikan oleh Herbert sebagai 'pengajaran yang mendidik.

7. William T. Harris, tokoh dari Amerika Serikat hidup pada tahun 1835- 
1909. Harris yang pandangannya dipengaruhi oleh Hegel berusaha menerapkan idealisme obyektif pada pendidikan umum. Tugas pendidikan baginya adalah mengizinkan terbukanya realita berdasarkan susunan yang pasti, berdasarkan kesatuan spiritual. Kedudukan sekolah adalah sebagai lembaga yang memelihara nilai-nilai yang telah turun temurun dan menyesuaikan penuntun penyesuaian diri kepada masyarakat.

Dalam rangka mempertahankan pahamnya itu, khususnya dari persaingan dengan paham progressivisme, tokoh-tokoh esensialisme mendirikan suatu organisasi yang bernama "Essentialist Committee for the Advancement of Education" pada tahun 1930. Melalui organisasinya inilah pandangan-pandangan esensialisme dikembangkan dalam dunia pendidikan. Sebagaimana telah disinggung di muka bahwa esensialisme mempunyai pandangan yang dipengaruhi oleh paham idealisme dan realisme, maka konsep-konsepnya tentang pendidikan sedikit banyak ikut diwarnai oleh konsepkonsep idealisme dan realisme.

Tujuan umum aliran esensialisme adalah membentuk pribadi bahagia di dunia dan akhirat. Isi pendidikannya mencakup ilmu pengetahuan, kesenian dan segala hal yang mampu menggerakkan kehendak manusia. Kurikulum sekolah bagi esensialisme merupakan semacam miniatur dunia yang bisa dijadikan sebagai ukuran kenyataan, kebenaran dan kegunaan. Maka dalam sejarah perkembangannya, kurikulum esensialisme menerapkan berbagai pola kurikulum, 
seperti pola idealisme, realisme dan sebagainya. ${ }^{10}$ Sehingga peranan sekolah dalam menyelenggarakan pendidikan bisa berfungsi sesuai dengan prinsip-prinsip dan kenyataan social yang ada di masyarakat.

\section{Aliran Perennialisme}

Perennialisme diambil dari kata perennial, yang dalam Oxford Advanced learner's Dictionary of Current English diartikan sebagai "continuing throughout the whole year" atau "Lasting for a very long time". Dari makna yang terkandung dalam kata itu aliran perennialisme mengandung kepercayaan filsafat yang berpegang pada nilai-nilai dan norma-norma yang bersifat kekal abadi.

Perennialisme melihat bahwa akibat dari kehidupan zaman modem telah menimbulkan banyak krisis di berbagai bidang kehidupan umat manusia. Untuk mengatasi krisis ini perennialisme memberikan jalan keluar berupa "kembali kepada kebudayaan masa lampau ${ }^{11}$ regressive road to culture. Oleh sebab itu perennialisme memandang penting peranan pendidikan dalam proses mengembalikan keadaan manusia zaman modern ini kepada kebudayaan masa lampau yang dianggap cukup ideal dan yang telah terpuji ketangguhannya. Sikap kembali pada masa lampau bukanlah berarti nostalgiasikap yang membanggakan kesuksesan dan memulihkan kepercayaan pada nilainilai asasi abad silam yang juga diperlukan dalam kehidupan abad modern.

\footnotetext{
${ }^{10}$ Muhammad Noor Syam, op. cit., hal. 153.

${ }^{11}$ Ibid, hal. 158
} 
Asas yang dianut perennialisme bersumber pada filsafat kebudayaan yang berkiblat dua, yaitu (a) perennialisme yang theologies-bernaung di bawah supremasi gereja Katolik, dengan orientasi pada ajaran dan tafsir Thomas Aquinas-dan (b) perennialisme sekuler berpegang pada ide dan cita filosofis Plato dan Aristoteles. ${ }^{12}$

Di bidang pendidikan, perennialisme sangat dipengaruhi oleh tokoh-tokohnya: Plato, Aristoteles dan Thomas Aquinas. Dalam hal ini pokok pikiran Plato tentang ilmu pengetahuan dan nilai-nilai adalah manifestasi dari pada hukum universal yang abadi dan sempuma, yakni ideal, sehingga ketertiban sosial hanya akan mungkin bila ide itu menjadi ukuran, asas normatif dalam tata pemerintahan. Maka tujuan utama pendidikan adalah "membina pemimpin yang sadar dan mempraktekkan asas-asas normatif itu dalam semua aspek kehidupan.

Menurut Plato, manusia secara kodrati memiliki tiga potensi, yaitu: nafsu, kemauan dan pikiran. Pendidikan hendaknya berorientasi pada potensi itu dan kepada masyarakat, agar supaya kebutuhan yang ada pada setiap lapisan masyarakat bisa terpenuhi. Ide-ide Plato itu dikembangkan oleh Aristoteles dengan lebih mendekatkan kepada dunia kenyataan. Bagi Aristoteles, tujuan pendidikan adalah "kebahagiaan". Untuk mencapai tujuan pendidikan itu, maka aspek jasmani, emosi dan intelek harus dikembangkan secara seimbang. Seperti halnya prinsip-prinsip Plato dan Aristoteles, tujuan pendidikan yang dimulai oleh

\footnotetext{
${ }^{12}$ Ibid., hal. 159.
} 
Thomas Aquinas adalah sebagai "Usaha mewujudkan kapasitas yang ada dalam individu agar menjadi aktualitas" aktif dan nyata. Dalam hal ini peranan guru adalah mengajar-memberi bantuan pada anak didik untuk mengembangkan potensi-potensi yang ada padanya.

Prinsip-prinsip pendidikan perenialisme tersebut perkembangannya telah mempengaruhi sistem pendidikan modern, seperti pembagian kurikulum untuk sekolah dasar, menengah, perguruan tinggi dan pendidikan orang dewasa.

\section{Aliran Rekonstruksionalisme}

Pada dasarnya aliran rekonstruksionalisme adalah sepaham dengan aliran perennialisme dalam hendak mengatasi krisis kehidupan modern. Hanya saja jalan yang ditempuhnya berbeda dengan apa yang dipakai oleh perennialisme, tetapi sesuai dengan istilah yang dikandungnya, yaitu berusaha membina suatu konsensus yang paling luas dan paling mungkin tentang tujuan utama dan tertinggi dalam kehidupan manusia-restore to the original form.

Untuk mencapai tujuan itu, rekonstruksionalisme berusaha mencari kesepakatan semua orang mengenai tujuan utama yang dapat mengatur tata kehidupan manusia dalam suatu tatanan baru seluruh lingkungannya. Maka melalui lembaga dan proses pendidikan, rekonstruksionalisme ingin "merombak tata susunan lama, dan membangun tata susunan hidup kebudayaan yang sama sekali baru ${ }^{13}$ Di sini nampak ada kesamaan dengan Dewey dalam "education as reconstruction".

\footnotetext{
${ }^{13}$ Muhammad Noor Syam, op. cit., hal. 183.
} 
Dalam rangka mewujudkan cita-cita pendidikan yang dimaksud di atas, diperlukan adanya kerja sama semua bangsa-bangsa.

Para penganut aliran rekonstruksionalisme berkeyakinan bahwa bangsa-bangsa di dunia mempunyai hasrat yang sama untuk menciptakan satu dunia baru, dengan satu kebudayaan baru di bawah satu kedaulatan dunia, dalam pengawasan mayoritas umat manusia. Barangkali pikiran-pikiran rekonstruksionalisme inilah yang kemudian menjiwai pandangan pemuka-pemuka dunia, seperti yang terumuskan dalam North - South: A Program For Survival (The Report of the Independent Commission on International Development Issues under the Chairmanship of Willy Brandt - Dialog Utara Selatan komisi Willy Brandt dalam rangka menciptakan kelestarian dunia) dan No limits to Learning.Bridging The Human Gap (A Report to the Club of Rome - Diskusi kelompok Roma dalam rangka menanggulangi kesenjangan yang melanda kehidupan umat manusia dewasa ini).

\section{E. Aliran Eksistensialisme}

Eksistensialisme biasa dialamatkan sebagai salah satu reaksi dari sebagian terbesar reaksi terhadap peradaban manusia yang hampir punah akibat perang dunia kedua. $^{14}$ Dengan demikian eksistensialisme pada hakikatnya adalah merupakan aliran filsafat yang bertujuan mengembalikan keberadaan umat manusia sesuai dengan keadaan hidup asasi yang dimiliki dan dihadapinya.

${ }^{14}$ Fernando R. Molina, The Sources of Eksistentialism As Philophys, New Jersey, Prentice-Hall, 1969, hal. 1 
Sebagai aliran filsafat, eksistensialisme berbeda dengan filsafat eksistensi. Paham eksistensialisme secara radikal menghadapkan manusia pada dirinya sendiri, sedangkan filsafat eksistensi adalah benar-benar sebagai arti katanya, yaitu : "filsafat yang menempatkan cara wujud manusia sebagai tema sentral". ${ }^{15}$ Maka, di sini letak kesulitan merumuskan pengertian eksistensialisme-sebagai aliran filsafat. Bahkan para filosof eksistensialis sendiri tidak memperoleh perumusan yang sama tentang eksistensialisme itu perdefinisi. Secara. singkat Kierkegaard memberikan pengertian eksistensialisme adalah suatu penolakan terhadap suatu pemikiran abstrak, tidak logic atau tidak ilmiah. Eksistensialisme menolak segala bentuk kemutlakan rasional. ${ }^{16}$ Dengan demilkian aliran ini hendak memadukan hidup yang dimiliki dengan pengalaman, dan situasi sejarah yang isalami, dan tidak mau terikat oleh halhal yang sifatnya abstrak serta spekulatif. Baginya, segala sesuatu dimulai dari pengalaman pribadi, keyakinan yang tumbuh dari dirinya dan kemampuan serta keluasan jalan untuk mencapai keyakinan hidupnya.

Atas dasar pandangannya itu, sikap di kalangan kaum eksistensialisme atau penganut aliran ini seringkali nampak aneh atau lepas dari norma-norma umum. Kebebasan untuk freedom to. ${ }^{17}$ adalah lebih banyak menjadi ukuran dalam sikap dan perbuatannya.

Pandangannya tentang pendidikan, disimpulkan oleh Van Cleve Morris

\footnotetext{
${ }^{15}$ Fuad Hassan, Kita dan Kami, Bulan Bintang, Jakarta, 1974, hal. 7-8.

${ }^{16}$ Paul Roubiczek, Existentialism For and Against, Cambridge University Press, 1966, hal. 10.

${ }^{17}$ Fuad Hasan, op.cit., hal 71
} 
dalam Existentialism and Education, bahwa "Eksistensialisme tidak menghendaki adanya aturan-aturan pendidikan dalam segala bentuk". ${ }^{18}$ Oleh sebab itu eksistensialisme dalam hal ini menolak bentuk-bentuk pendidikan sebagaimana yang ada sekarang. Namun bagaimana konsep pendidikan eksistensialisme yang diajukan oleh Morris sebagai "existentialism's concept of freedom in education", menurut Bruce F. Baker, tidak memberikan kejelasan. Barangkali Ivan Illich dengan Deschooling Society, yang banyak mengundang reaksi di kalangan ahli pendidikan, merupakan salah satu model pendidikan yang dikehendaki aliran eksistensialisme. Di sini agaknya mengapa aliran eksistensialisme tidak banyak dibicarakan dalam filsafat pendidikan.

\section{IMPLIKASI ALIRAN-ALIRAN FILSAFAT TERHADAP PEMIKIRAN PENDIDIKAN ISLAM}

Terhadap dunia pendidikan Islam, berbagai perkembangan aliran-aliran filsafat diatas perlu kiranya membaca kembali produk pemikiran tersebut, untuk dijadikan pertimbangan dalam penerapannya, karena model yang ditawarkan masing-masing aliran juga berimplikasi terhadap pendidikan Islam. Implikasi itu dapat diuraikan sebagai berikut:

A. Perenial-esensialis Salafi, berupaya memahami ajaran-nilai yANg terkandung adalam al-Qur'an dan as-Sunnah yang shahih dengan melepaskan diri dan kurang

\footnotetext{
${ }^{18}$ Joe Park, op. cit. hal. 128-138 pat
} 
memperhatikan pergumulan masyarakat muslim (era klasik maupun kontemporer) yg mengitarinya. Masyarakat idealnya adalah salaf (era masa Nabi dan Sahabat) rujukan utama adalah al-Qur'an dan Sunnah tanpa menggunakan pendekatan keilmuan yg lain. Dalam konteks pemikiran pendidikan terdapat dua mazhab yang lebih dekat dengan tekstualis salafi, yaitu perenilaisme dan essensialisme, teruatama dilihat dari wataknya yang regresif dan konservatif. Hanya saja Perenialisme menghendaki agar kembali ke abad pertengahan, sedangkan model tekstualis salafi menghendaki agar kembali ke masyarakat salaf (era kanabian dan sahabat). Adapun Essensialism menghendaki pendidikan yang bersendikan atas nilai-nilai yg tinggi, yang hakiki kedudukannya dalam kebudayaan, dan nilai-nilai ini hendaklah yang sampai kepada manusia sivilisasi dan yang telah teruji oleh waktu. Model tekstual salafi juga beranggapan bahwa nilai-nilai kehidupan masyarakat salaf perlu dujunjung tinggi dan dilestarikan keberadaannya hingga sekarang, baik nilai-nilai insaniyah maupun nilai Ilahiyah, karena keduanya berwatak konservatif dalam arti sama-sama hendak memepertahankan nilai, kebiasaan dan tradisi masyarakat terdahulu.

Model tekstual salafi selain menyajikan secara manquli, yakni memahami atau menafsirkan nash-nash tentang pendidikan dengan nash-nash lain atau dengan menukil dari pendapat sahabat, juga berusaha membangun konsep pendidikan Islam melalui kajian tekstual lughawi atau berdasarkan kaidah-kaidah bahasa Arab dalam memahami nash-nash al-Qur'an.

B. Perenial esensialis Mazhabi, berupaya memahami ajaran al-Qur'an dan Sunnah 
melaui khazanah pemikiran klasik tanpa memepertimbangkan situasi sosio-historis masyarakat setempat dimana ia turut hidup didalamnya. Hasil pemikiran/ijtihad ulama terdahulu dianggab sidah final atau absolut tanpa memepertimbangkan dimensi historisitasnya.Kitab kuning menjadi rujukan pokok dan sulit keluar dari mazhab atau pemikiran keislaman yg terbentuk abad lalu. Jadi yng menonjol watak tradisionalnya dan mazhab. Watak tradisional diwujudkan dalam bentuk sikap dan cara berfikir serta bertindak yng selau berpegang teguh kepada nilai, norma, adat istiadat, kebiasaan serta pola pikir yang yang ada secara turun-temurun, tidak mudah mengalami perubahan dan perkembangan. Sedangkan mazhabinya terwujud dari dalam bentuk kecenderungan untuk mengikuti aliran, pemahaman atau doktrin, serta pola-pola pemikiran sebelumnya yang sudah dianggab relatif mapan.

C. Modernis, berupaya memahami ajaran dan nilai-nilai mendasar dari ajaran alQur' an dan Hadis denga hanya semata mempertimbangkan kondisi dan tantangan sosio-kutural yang dihadapi masyarakat muslim kontemporer tanpa mempertimbangkan muatan-muatan khazanah intelektual klasik yang terkait dengan persoalan-persoalan keagamaan dan kemasyarakatan. Dalam kontek pemikiran pendidikan yang lebih dekat dengan model pemikiran modernis adalah Progresvisme terutama dalam wataknya ingin bebas dan modifikatif. Yaitu menghendaki pendidikan yang pada hakeikatnya progresif, tujuan pendidikan hendaknya diartikan sebagai 
rekonstruksi pengalaman yang terus-menerus, agar peserta didik dapat berbuat sesuatu ynga inteligen dan mampu mengadakan penyesuaian degn tuntunan lingkungan.

D. Neo-Modernis (Perenial-essensialis kontekstual-falsifikatif). Berupaya memahami ajaran-nilai yg terkandung adalam al-Qur'an dan Sunnah al-shahihah dengan mengikut-sertakan dan mempertimbangkan khazanah intelektual muslim kalsik serta mencermati kesulitan-kesulitan dan kemudahan-kemudahan yg ditawarkan oleh dunia teknologi modern. Jargon yang dikumandangkan adalah Al-Muhafazhah 'ala alQadim al-Shalih wa al-akhzu bi al-Jadid al-Ashlah”, yakni memelihara hal-hal yang baik yang telah ada sambila mengembangkan nilai-nilai baru yang lebih baik"

Kata "Al-Muhafazhah "ala al-Qadim" menggaris bawahi adanya unsur Perenial-essensialis, yakni sikap regresif dan konservatif terhadap nilai-nilai insani (budaya manusia) yang telah ada dan dibangun sereta dikembangkan oleh pemikir dan masyarakat terdahulu. Tetapi sikap itu muncul setelah dilakukan kontekstualisasi, dalam arti mendudukkan khazanah intelektual muslim klasik dalam konteksnya. Pemikiran-pemikiran mereka bukan bebas dari kritik atau undebatable (tidak bisa diperdebatkan atau dikritisi) terutama dalam konteks keberlakuannya pada masa sekarang. Karl R. Popper menawarkan prinsip falsifikatif, yaitu bahwa suatu pemikiran, teori atau ucapan bersifat ilmiyah kalau terdapat kemungkinan ubtuk menyatakan salahnya, atau dilakukan uji falsifikasi terutama dikaitkan dengan keberlakuan atau ketidak-berlakuannya pada kasus-kasus tertentu atau menguji relevan atau tidaknya pemikiran mereka dalam konteks masa sekarang dengan menggunakan pendekatan keilmuan yang ada. Hal-hal yang bersifat relevan akan 
disikapi dengan cara al-Akhzu bi al-jadid al-ashlah, yakni mencari alternatif lain yag lebih baik dalam konteks pendidikan masyarakat muslim kontemporer. Kata al-akhzu bi al-Jadid al-Ashlah, ini menunjukkan sikap dinamis dan progresif serta sikap konstruktif walaupun tidak bersifat radikal.

E. Rekonstruksi Sosial menurut Muhajir pemikiran pendidikan yang hendak mengembangkan wawasan antisipasi masa depan, berdasarkan pada pemikiran bahwa manusia adalah konstruktivist, bahkan konstruktivist sosial.Pada era post modern dg ciri percepatan perubahan ilmu pengetahuan dan teknologi dan perubahan infrastruktur sosial serta perkembangan tuntutan dunia kerja menjadi semakin penting memerlukan persiapan lebih intens.Dan lebih esensial lagi bahwa dan percepatan, perkembangan dan tuntutan tersebut semakin banyak yang tak terduga dan semakin eksponensial. Oleh karena itu pendidikan bukan lagi sebatas membekalkan kemampuan menjadi konstruktivist sosial, melainkan membekalkan agar secara berkelanjutan mampu mengadakan rekonstruksi sosial.Filsafat pendidikan tersebut berangkat dari bottom-up yang dibangun dari grass root, dalam pluralisme, dan dalam konteks mengejar keunggulan. Berbeda dengan rekonstruksi sosial tahun 1970-an yang tipdown dan lebih berorientasi ke teknis planning. Menurut Muhajir (2000) bahwa kompleksitas kehidupan pluralistik menurut sseorang untuk tidak menampilkan konstruk tertentu yang cloced ended, tetapi menampilkan konstruk yang terus dikembangkan bolak balik antara empiri dan konsep teori. Karena percepatan perubahan sosial dan nilai-nilai lainnya semakin tak terduga, maka rekonstruksi sosial tersebut perlu dikembangkan postparadigmatik, yakni paradigmanya terus 
dikembangkan. Jadi pemikiran ini lebih bersifat proaktif dan antisipatif. Dikatakan proaktif, berusaha untuk mencari jawaban dan sekaligus memperkirakan perkembangan kedepan dan kondisi serta permasalahan yanga ada. Sedangkan antisipatif, karena ia berusaha mengkondisikan situasi, kondisi dan faktor menjadi lebih ideal.

\section{Penutup}

Berdasarkan berbagai analisis dalam aliran-alairan filsafat Pendidikan Islam dengan berbagai pandangan aliran progrrssivisme, essensialisme, parennialisme, parennealisme, rekonstruksialisme, eksistensialisme dapat diberikan kesimpulan:

1. Aliran progrrssivisme memiliki pandangan hidup yang mempunyai sifat-sifat fleksibel (tidak kaku, tidak menolak perubahan, tidak terikat oleh suatu doktrin tertentu), curious (ingin mengetahui, ingin menyelidiki), toleran dan open-minded (mempunyai hati terbuka). Dengan aliran ini pendidikan Islam dapat diterapkan materi pengajaran pendidikan dapat menerima dan menjawab tantangan jaman seperti permasalahan umat Islam dapat diajarkan di sekolah/madrasah dalam bentuk kurikulum.

2. Aliran essensialisme berpandangan bahwa pendidikan harus berpijak pada nilai-nilai yang memiliki kejelasan dan tahan lama, sehingga memberikan kestabilan dan arah yang jelas. Pandangan ini dapat diterapkan dalam dunia pendidikan Islam dengan cara kurikulum sekolah bersifat humanistik dan 
bersifat internasional, sehingga bisa mencakup lapisan menengah dan kaum aristokrat.

3. Aliran parennialisme mengandung kepercayaan filsafat yang berpegang pada nilai-nilai dan norma-norma yang bersifat kekal abadi. Tujuan utama aliran ini dalam pendidikan adalah "membina pemimpin yang sadar dan mempraktekkan asas-asas normatif itu dalam semua aspek kehidupan.

4. Aliran rekonstruksialisme berpendapat bahwa untuk dapat membina masyarakat diperlukan usaha membina suatu konsensus yang paling luas dan paling mungkin tentang tujuan utama dan tertinggi dalam kehidupan manusia-restore to the original form dan "merombak tata susunan lama, dan membangun tata susunan hidup kebudayaan yang sama sekali baru. Dalam system pendidikan Islam dapat diajarkan hal-hal baru dalam sosial dengan didasari argumentasi agama yang sesuai dengan norma agama.

5. Aliran eksistensialisme berpandangan suatu penolakan terhadap suatu pemikiran abstrak, tidak logik atau tidak ilmiah dengan menolak segala bentuk kemutlakan rasional. aliran ini hendak memadukan hidup yang dimiliki dengan pengalaman, dan situasi sejarah yang isalami, dan tidak mau terikat oleh hal-hal yang sifatnya abstrak serta spekulatif.

A. Implikasi

Berdasarkan analisis pandangan beberapa substansi pembahasan berbagai aliran filsafat dan penerapan dalam pembelajaran Pendidikan Islam dapat berimplikasi pada: 
1. Pemahaman penggunaan pandangan berbagai aliran-aliran filsafat dalam pendidikan Islam sangat diperlukan bagi steack holder pendidikan Islam. Agar tujuan pendidikan Islam dapat terarah dan menjawab berbagai permasalahan Pendidikan Islam.

2. Lembaga pendidikan Islam wajib mengetahui berbagai pandangan aliran filsafat, untuk dapat menerapkan kepentingan dakwah Islamiyah dalam kehidupan masyarakat yang majemuk dalam kehidupan berbangsa dan bernegara khusus di Negara Indonesia. 


\section{DAFTAR PUSTAKA}

Abdullah, Abdurrahman Saleh, Education Theory A Quranic Out-look, Makalah alMukarramah: Umm al-Qura University, 1982.

Noorsyam, M., Pengantar Filsafat Pendidikan, Malang: IKIP Malang, 1978.

Brameld, Theodore, The Pattern of Educational Philosophy, The Mac. Milian Company, New York, 1956.

Park, Joe, Selected Readings in the Philosophy of Education, New York, Mackn Publishing Co, Inc. 1974

Barnadib, Imam, FlIsafat Pendidikan, Cet. IX, Yogyakarta: Yayasan Penerbit FIP IKIP, 1997.

Molina, Fernando R., The Sources of Eksistentialism As Philophys, New Jersey, Prentice-Hall, 1969.

Hassan, Fuad, Kita dan Kami, Bulan Bintang, Jakarta, 1974.

Roubiczek, Paul, Existentialism For and Against, Cambridge University Press, 1966

Soedomo, M., Aktualisasi Pengembangan Ilmu Pendidikan Islam Dalam Pembangunan Nasional, Malang: IKIP, 1990. 